\title{
Antigenic relationships among type-1 fimbriae of Enterobacteriaceae revealed by immuno- electronmicroscopy
}

\author{
R. A. ADEGBOLA* and D. C. OLD \\ Department of Medical Microbiology, University of Dundee Medical School, Ninewells Hospital, \\ Dundee DD1 9SY
}

\begin{abstract}
Summary. Antigenic relationships among type-1 fimbriae of 40 strains of Enterobacteriaceae representing 19 species and seven genera were determined by immunoelectronmicroscopy. Ten distinct antigenic groups were distinguished. Intra- and inter-generic relationships were observed although some antigenic groups were species-specific only. Antigenic relationships among type-1 fimbriae are more complex than have been reported hitherto.
\end{abstract}

\section{Introduction}

Type-1 fimbriae are of common occurrence in the family Enterobacteriaceae (Duguid and Old, 1980), including the newly described species and genera of the tribe Klebsielleae (Adegbola, 1983). All type-1 fimbriae are similar morphologically and in adhesive properties, as suggested by their mannose-sensitive haemagglutination of certain erythrocyte species (Duguid and Gillies, 1957; Duguid, 1959; Duguid et al., 1966; Salit and Gotschlich, 1977).

Type-1 fimbriae are antigenic (Gillies and Duguid, 1958) and share serological relationships with non-haemagglutinating type-2 fimbriae of salmonellae (Old and Payne, 1971) but not with the type-3 fimbriae of Klebsiella (Nowotarska and Mulczyk, 1977; Adegbola, 1983; Korhonen et al., 1983; Old et al., 1985). Agglutination tests have been used to demonstrate sharing of type-1 fimbrial antigens among: (i) Escherichia, Shigella and, to a lesser extent, Klebsiella (Gillies and Duguid, 1958); (ii) Citrobacter and Salmonella (Duguid and Campbell, 1969). There was, however, no sharing of type1 fimbrial antigens between salmonellae on the one hand and Escherichia coli and Shigella flexneri on the other (Duguid and Campbell, 1969). Less is known, however, about the antigens of type-1 fimbriae on other strains of Enterobacteriaceae (Duguid, 1985).

Recent studies have revealed that multiple

Received 29 Jul. 1986; accepted 1 Sep. 1986.

* Present address: Department of Biological and Chemical Sciences, Lagos State University, Badagry Expressway, Ojo, PMB 1087, Apapa, Lagos, Nigeria. fimbriation is a common phenomenon among enterobacteria (Duguid and Old, 1980; Adegbola and Old, 1982; Old and Adegbola, 1982; Adegbola et al., 1983). Thus, previous serological reports based on agglutination tests should be interpreted with caution because agglutination tests are unlikely to be adequate for satisfactory antigenic characterisation of the different types of fimbriae that might be formed by a single bacterial strain.

In the present study, we used immuno-electronmicroscopy (IEM), in which type-1 fimbriae were specifically labelled by attachment of type-1 fimbrial antibody, to assess the degree of relatedness among type-1 fimbriae present on strains from 19 species of Enterobacteriaceae.

\section{Materials and methods}

\section{Bacteria}

We examined 40 strains of 19 species of Enterobacteriaceae, six of which were also used as vaccine strains. All strains were identified by API-20E tests; in some cases, conventional tests such as carbon-source utilisation and growth in metahydroxybenzoate (Richard, 1977) were used to identify strains to species rank. Strains were stored at $4^{\circ} \mathrm{C}$ on slants of nutrient agar or Dorset's egg medium until subcultured for testing. Their sources, biotypes and haemagglutination status with corresponding fimbriae are detailed (table I).

\section{Media and culture methods}

These have been described before (Adegbola and Old, 1982 and 1983; Old and Adegbola, 1983). 
Table I. Strains of Enterobacteriaceae

\begin{tabular}{|c|c|c|c|c|}
\hline $\begin{array}{l}\text { Bacterial } \\
\text { species }\end{array}$ & $\begin{array}{c}\text { Donor } \\
\text { or } \\
\text { source* }\end{array}$ & $\begin{array}{c}\text { Strain } \\
\text { no. }\end{array}$ & $\begin{array}{c}\text { Type-1 } \\
\text { fimbriae }\end{array}$ & $\begin{array}{c}\text { Other fimbriae (and associated } \\
\text { haemagglutinins } \dagger \text { ) }\end{array}$ \\
\hline C. freundi & NCTC & 6021 & + & none \\
\hline C. freundi & NCTC & 6267 & + & none \\
\hline C. freundi & NCTC & 6071 & + & none \\
\hline C. freundi & NCTC & 9737 & + & none \\
\hline Ent. aerogenes & NCTC & 10006 & + & thin (MS, MR/P) \\
\hline Ent. aerogenes & NCTC & 10336 & + & thin (MS, MR/P) \\
\hline Ent. amnigenus & CUETM & $78-77$ & + & none \\
\hline Ent. amnigenus & $\mathrm{CDC}$ & $2419-80$ & + & none \\
\hline Ent. cloacae & JPD & 035 & + & none \\
\hline Ent. cloacae & NCTC & 10005 & + & none \\
\hline Ent. intermedium & CUETM & $77-123$ & + & none \\
\hline Ent. intermedium & CDC & $1167 / 81$ & + & none \\
\hline Ent. sakazaki & JPD & 889 & + & none \\
\hline Ent. sakazaki & NCTC & 8155 & + & none \\
\hline K. pneumoniae & JPD & $\mathrm{K} 40 / 1$ & + & none \\
\hline ss. aerogenes & JPD & $\mathrm{K} 55 / 1$ & + & none \\
\hline$K$. pneumoniae ss. & JPD & $\mathrm{K} 3 / 8$ & + & none \\
\hline pneumoniae & JPD & 204 & + & none \\
\hline P. vulgaris & NCTC & 4175 & $-\ddagger$ & thick (MS, MR/K, MR/P) \\
\hline P. vulgaris & NCTC & 10376 & - & thick (MS, MR/K, MR/P) \\
\hline Prov. alcalifaciens & JLP & 248 & - & thick (MS, MR/K) \\
\hline Prov. alcalifaciens & $\mathrm{CDC}$ & 9259 & - & thin, thick (MS, MR/K) \\
\hline Prov. rettgeri & NCTC & 7477 & - & thin, thick (MS, MR/K) \\
\hline Prov. rettgeri & JLP & 3881 & - & thin, thick (MS, MR/K) \\
\hline Prov. stuarti & JLP & CH5100 & - & thick (MS, MR/K) \\
\hline Prov. stuarti & NCTC & 10318 & - & thick (MS, MR/K) \\
\hline Prov. stuarti & NCTC & 10834 & - & thick $(\mathrm{MR} / \mathrm{P})$ \\
\hline S. arizonae & SA & $3600-56$ & + & thin $(\mathrm{MR} / \mathrm{K})$ \\
\hline S. arizonae & NCTC & 7311 & + & none \\
\hline S. enteritidis & SA & $224-36 / 73 v$ & + & none \\
\hline S. enteritidis & DU & $41725 / 82$ & + & none \\
\hline S. typhimurium & SA & $162-36 / 72 v$ & + & none \\
\hline S. typhimurium & SA & $221-36 / 73 v$ & + & none \\
\hline S. virchow & DU & 79336 & + & none \\
\hline S. virchow & DU & 79352 & + & none \\
\hline Ser. marcescens & PADG & $5(\mathrm{~A} 1)$ & + & thin $(\mathrm{MR} / \mathrm{K}, \mathrm{MR} / \mathrm{P})$ \\
\hline Ser. marcescens & NCTC & 2302 & + & thin $(M R / K)$ \\
\hline Ser. odorifera & PHG & 4013 & + & thin $(\mathbf{M R} / \mathbf{K})$ \\
\hline Ser. odorifera & PHG & 4017 & + & thin $(\mathbf{M R} / \mathbf{K})$ \\
\hline Ser. proteamaculans & PADG & 3894 & + & thin $(\mathrm{MR} / \mathrm{P})$ \\
\hline
\end{tabular}

${ }^{*} \mathrm{CDC}=$ Centers for Disease Control, Atlanta, GA, USA; CUETM $=$ Collection Unité d'Ecotoxicologie Microbienne, Villeneuve-d'Ascq, France; DU = Department of Medical Microbiology, Dundee University; JLP = Dr J. L. Penner, University of Toronto, Ontario, Canada $;$ JPD = Professor J. P. Duguid, University Medical School, Dundee; NCTC $=$ National Collection of Type Cultures, Central Public Health Laboratory, London; PADG $=$ Dr P. A. D. Grimont, Service des Entérobactéries, Unité INSERM, Institut Pasteur, Paris, France; PHG $=$ Professor Ph. Goullet, Service de Microbiologie, Hospital Beaujon, Clichy, France; SA = Dr S. Aleksić, National Salmonella Laboratory, Hamburg, West Germany.

†The haemagglutinins were of the kinds described by Duguid and Old (1980) as: $\mathrm{MS}=$ mannosesensitive; $\mathrm{MR} / \mathrm{K}=$ mannose-resistant and klebsiella-like; $\mathrm{MR} / \mathrm{P}=$ mannose-resistant and proteus-like.

¥The production of MS-HA by Proteeae has still to be definitively associated with the presence of thick, type 1-like fimbriae found on many strains; accordingly, these fimbriae have not been designated as type-1 (see Old and Adegbola, 1982). 


\section{Haemagglutination tests}

Each bacterial culture was shown to be in the fimbriate state by haemagglutination tests with different species of erythrocytes in the absence and presence of D-mannose. Adequate preparation of erythrocyte suspensions and careful performance of haemagglutination tests are essential for full characterisation of the haemagglutinating properties of the strains. These and the characterisation of the mannose-sensitive haemagglutinin (MS-HA), the mannose-resistant and klebsiella-like haemagglutinin (MR/K-HA) and the mannose-resistant and proteus-like haemagglutinin (MR/P-HA) have been fully described elsewhere (Adegbola and Old, 1982 and 1983; Old and Adegbola, 1982; Old, 1985).

\section{Preparation of type-1 fimbrial antiserum}

Antisera were raised in adult rabbits as described by Adegbola and Old (1982). $O$ and, where necessary, $H$ antibodies were removed from crude antiserum by the methods of Old and Adegbola (1985). By these procedures antisera specific for type-1 fimbriae were prepared against fimbriate cultures of: $S$. paratyphi B strain S543; $K$. pneumoniae ss. aerogenes strain $\mathrm{K} 55 / 1$; and Enterobacter cloacae strain O35, each of which formed MS-HA and type-1 fimbriae only. The vaccine strains Serratia marcescens NCTC 2302 and Ser. odorifera PHG 4013 formed, in addition to type-1 fimbriae, type- 3 fimbriae and MR/ K-HA (table I). Their type-3 fimbriae are antigenically related to those of Ser. plymuthica strains which form type-3 fimbriae only (Adegbola and Old, 1982; Old et al., 1983). To obtain specific type-1 fimbrial antisera against these latter two vaccine strains, type- 3 fimbrial antibodies were removed by repeated absorptions at $37^{\circ} \mathrm{C}$ for $1 \mathrm{~h}$ with dense bacterial suspensions of type- 3 fimbriae-rich cultures of Ser. plymuthica that had been grown in large volumes of nutrient broth at $30^{\circ} \mathrm{C}$ for $48 \mathrm{~h}$ and washed twice, and resuspended to $c .5 \times 10^{11}$ bacteria $/ \mathrm{ml}$, in saline. Absorptions were continued until 1 in 10 and 1 in 20 dilutions of these latter antisera did not agglutinate type-3 fimbriate cultures of Ser. plymuthica or coat the type- 3 fimbriae of these two vaccine strains as seen with the electronmicroscope.

Multiple fimbriation is a common phenomenon among strains of Morganella, Proteus and Providencia (Adegbola, 1981; Old and Scott, 1981; Old and Adegbola, 1982). However, "thick" and channelled fimbriae, morphologically similar to type-1 fimbriae but associated instead with a weak mannose-resistant agglutination of fcwl and guinea-pig erythrocytes, were the only type of fimbriae produced by Prov. stuarti strain NCTC 10834 (Old and Adegbola, 1982). Fimbrial antiserum against these "thick" fimbriae of Providencia strains coated the "thick", channelled fimbriae of MS-HA ${ }^{+}$strains of Prov. stuarti (Adegbola, 1981); antiserum against Prov. stuarti strain 10834 was included in this study.

\section{Electronmicroscopy}

The technique has been described before (Adegbola and Old, 1982; Old and Adegbola, 1982). Most bacterial cultures were negatively stained for $1 \mathrm{~min}$ with uranyl acetate $(p \mathrm{H} \mathrm{4.6)} 0.3 \% \mathrm{w} / \mathrm{v}$ (Adegbola and Old, 1982). Some kinds of fimbriae of strains of Proteus and Providencia are acid-labile (Adegbola, 1981; Old and Adegbola, 1982). Accordingly, methylamine tungstate $(p \mathrm{H} \mathrm{6.5)}$ (a commercial preparation from EMscope Laboratories Ltd, Ashford, Kent) was used for negative staining of cultures of these latter genera. The electronmicroscope was a Jeol $100 \mathrm{CX}$ model; micrographs of fimbriae, uncoated or coated with fimbrial antibody, were taken as described previously (Adegbola and Old, 1982; Old and Adegbola, 1982).

\section{Immuno-electronmicroscopy}

Fimbriate cultures were also negatively stained, as described by Adegbola and Old (1982), after treatment with fimbrial antiserum. Degrees of antibody coating of type-1 fimbriae were estimated with the electronmicroscope and scored on an arbitrary scale from 0 (no coating) to +++ (maximum coating) as described elsewhere (Adegbola and Old, 1982). Grids with bacteria alone or bacteria treated with pre-immunisation sera were included as controls.

\section{Results}

\section{Haemagglutinins and fimbriae}

Twenty-three of the 40 strains examined formed MS-HA only; 16 other strains formed MS-HA as well as MR/K-HA or MR/P-HA or both (table II). Prov. stuarti strain NCTC 10834 was the only one of the 40 strains that did not form MS-HA. All MS$\mathrm{HA}^{+}$strains had formed MS-HA, demonstrable in tests with red cells of fowl or guinea pig, by the third or fourth serial subculture in any series. However, the MS-HAs of strains of Proteus and Providencia were best demonstrated at the first or second subculture in any series because thereafter the simultaneous production of MR/P-HA masked the presence of MS-HA (see Old and Adegbola, 1982).

All MS-HA ${ }^{+}$strains formed thick (c. $8 \mathrm{~nm}$ wide), channelled fimbriae observed with the electronmicroscope. Prov. stuarti strain NCTC 10834, though $\mathrm{MS}-\mathrm{HA}^{-}$, also formed thick, channelled fimbriae morphologically indistinguishable from the type- 1 fimbriae produced by MS- $\mathrm{HA}^{+}$strains.

\section{Immuno-electronmicroscopy}

Haemagglutinating bacteria of the 39 strains which formed MS-HA and were rich in type-1, or 
Table II. Serological relationships among type-1 fimbriae of Enterobacteriaceae revealed by immuno-electronmicroscopy

Degree of antibody coating* of type-1 fimbriae of stated species in IEM tests with type-1 fimbrial antiserum against

\begin{tabular}{|c|c|c|c|c|c|c|c|}
\hline & & & & \\
\hline $\begin{array}{l}\text { Bacterial } \\
\text { species }\end{array}$ & $\begin{array}{l}\text { Strain } \\
\text { no. }\end{array}$ & $\begin{array}{c}\text { S. para- } \\
\text { typhi B } \\
\text { S543 }\end{array}$ & $\begin{array}{c}\text { K. pneu- } \\
\text { moniae ss. } \\
\text { aerogenes } \\
\text { K55/1 }\end{array}$ & $\begin{array}{c}\text { Ent. cloacae } \\
035\end{array}$ & $\begin{array}{c}\text { Ser. marcescens } \\
2302\end{array}$ & $\begin{array}{c}\text { Ser. odorifera } \\
4013\end{array}$ & $\begin{array}{c}\text { Prov. stuarti } \\
10834\end{array}$ \\
\hline S. arizonae & $3600-56$ & +++ & 0 & 0 & 0 & $\mathbf{0}$ & 0 \\
\hline S. arizonae & 7311 & +++ & 0 & 0 & 0 & 0 & 0 \\
\hline S. enteritidis & $224-36 / 73 v$ & ++ & $\mathbf{0}$ & 0 & $\mathbf{0}$ & 0 & 0 \\
\hline S. enteritidis & $41725 / 82$ & ++ & 0 & 0 & 0 & $\mathbf{0}$ & 0 \\
\hline S.typhimurium & $162-36 / 72 v$ & +++ & 0 & 0 & 0 & 0 & 0 \\
\hline S. typhimurium & $221-36 / 73 v$ & +++ & 0 & 0 & 0 & 0 & 0 \\
\hline S. virchow & 79336 & +++ & 0 & 0 & 0 & 0 & 0 \\
\hline S. virchow & 79352 & +++ & 0 & 0 & 0 & 0 & 0 \\
\hline C. freundi & 6021 & ++ & 0 & 0 & 0 & 0 & 0 \\
\hline C. freundi & 6267 & +++ & 0 & 0 & 0 & 0 & 0 \\
\hline C. freundi & 6071 & 0 & +++ & 0 & 0 & 0 & 0 \\
\hline C. freundi & 9737 & 0 & +++ & 0 & $\mathbf{0}$ & 0 & 0 \\
\hline K. pneumoniae ss. & $\mathrm{K} 40 / 1$ & 0 & +++ & 0 & 0 & 0 & 0 \\
\hline aerogenes & $\mathrm{K} 55 / 1$ & 0 & ++ & 0 & 0 & 0 & 0 \\
\hline$K$. pneumoniae ss. & $\mathrm{K} 3 / 8$ & 0 & +++ & 0 & $\mathbf{0}$ & $\mathbf{0}$ & 0 \\
\hline pneumoniae & 204 & 0 & ++ & 0 & 0 & 0 & 0 \\
\hline Ent. aerogenes & 10006 & 0 & +++ & 0 & 0 & 0 & 0 \\
\hline Ent. aerogenes & 10336 & 0 & +++ & 0 & 0 & 0 & 0 \\
\hline Ent. amnigenus & $78-77$ & 0 & 0 & +++ & 0 & 0 & 0 \\
\hline Ent. amnigenus & $2419-80$ & 0 & 0 & +++ & 0 & 0 & 0 \\
\hline Ent. cloacae & 035 & 0 & 0 & +++ & 0 & 0 & 0 \\
\hline Ent. cloacae & 10005 & 0 & 0 & +++ & 0 & 0 & $\mathbf{0}$ \\
\hline Ent. sakazaki & 889 & 0 & 0 & +++ & 0 & 0 & 0 \\
\hline Ent. sakazaki & 8155 & 0 & 0 & $++t$ & 0 & 0 & 0 \\
\hline Ent. intermedium & $77-123$ & 0 & 0 & 0 & 0 & 0 & 0 \\
\hline Ent. intermedium & $1167 / 81$ & 0 & 0 & 0 & 0 & 0 & 0 \\
\hline Ser. marcescens & $5(\mathrm{Al})$ & 0 & 0 & 0 & +++ & 0 & 0 \\
\hline Ser. marcescens & 2302 & 0 & 0 & 0 & ++ & 0 & 0 \\
\hline Ser. proteamaculans & 3894 & 0 & 0 & 0 & ++ & 0 & 0 \\
\hline Ser. odorifera & 4013 & 0 & 0 & 0 & 0 & +++ & 0 \\
\hline Ser. odorifera & 4017 & 0 & 0 & 0 & 0 & ++ & 0 \\
\hline Prov. stuarti & CH5100 & 0 & 0 & 0 & 0 & 0 & +++ \\
\hline Prov. stuarti & 10318 & 0 & 0 & 0 & 0 & 0 & +++ \\
\hline Prov. stuarti & 10834 & 0 & 0 & 0 & 0 & 0 & +++ \\
\hline P. vulgaris & 4175 & 0 & 0 & 0 & 0 & 0 & 0 \\
\hline P. vulgaris & 10376 & 0 & 0 & 0 & 0 & 0 & 0 \\
\hline Prov. alcalifaciens & 248 & 0 & 0 & 0 & 0 & 0 & 0 \\
\hline Prov. alcalifaciens & 9259 & 0 & 0 & 0 & 0 & 0 & 0 \\
\hline Prov. rettgeri & 7477 & 0 & 0 & 0 & 0 & 0 & 0 \\
\hline Prov. rettgeri & 3881 & 0 & 0 & 0 & 0 & 0 & 0 \\
\hline
\end{tabular}

*Coating of fimbriae was: $+++=$ maximum; $0=$ absent.

other thick type 1-like, fimbriae were tested by IEM with each of the five type-1 fimbrial antisera (table II) and with the fimbrial antiserum specific for the thick (non-MS-HA) fimbriae of Prov. stuarti strain NCTC 10834. Several broad areas of serological relatedness were observed.

(i) Type-1 fimbrial antiserum against $S$. paratyphi
$B$ strain S543 strongly coated the type-1 fimbriae of all serotypes of Salmonella tested and of two strains of $C$. freundi (table II). Moreover, this fimbrial antiserum had strongly coated the type-1 fimbriae of many other serotypes of Salmonella and those of another ten strains of Citrobacter in another study (results not shown). The type-1, and other kinds of 
thick, fimbriae present on the other $29 \mathrm{MS}^{-\mathrm{HA}^{+}}$ strains of Enterobacteriaceae examined in this study were not coated by this antiserum (table II).

(ii) Type-1 fimbrial antiserum against $K$. pneumoniae ss. aerogenes strain K55/1 strongly coated the type-1 fimbriae on bacteria from $\mathrm{MS}-\mathrm{HA}^{+}$ cultures of homologous and heterologous strains of that subspecies (results for only two strains shown; table II). It also strongly coated the type-1 fimbriae of strains of $K$. pneumoniae ss. pneumoniae and two of the four strains of $C$. freundi, and the thick fimbriae on bacteria from multiply haemagglutinating cultures of Ent. aerogenes (table II). Furthermore, this type-1 fimbrial antiserum had also coated the type-1 fimbriae of strains of four other species of Klebsiella (Old and Adegbola, 1984). It did not coat the type-1, or other thick, fimbriae of the other $31 \mathrm{MS}^{-\mathrm{HA}^{+}}$strains tested (table II).

(iii) The type-1 fimbriae of homologous and heterologous strains of Ent. cloacae (results for only two strains shown; table II) and those of Ent. amnigenus and Ent. sakazaki were coated by type-1 fimbrial antiserum against Ent. cloacae strain 035; those of Ent. intermedium and the other 33 MS$\mathrm{HA}^{+}$enterobacteria tested were not coated (table II).

(iv) The two type-1 fimbrial antisera against strains of Serratia gave different reactions. Thus, the antiserum against Ser. odorifera strain PHG 4013 coated the type-1 fimbriae of that species only. The type-1 fimbrial antiserum of Ser. marcescens strain NCTC 2302, on the other hand, coated the type-1 fimbriae of strains of Ser. marcescens and Ser. proteamaculans but not those of Ser. odorifera (table II). This antiserum had also coated the type1 fimbriae of four other species of Serratia strongly and those of Ser. rubidaea moderately (results not shown; Adegbola, 1983). Neither of the type-1 fimbrial antisera against serratiae coated the thick fimbriae of any other genus tested (table II).

(v) Antiserum against the thick (non-MS-HA) fimbriae of Prov. stuarti strain NCTC 10834 strongly coated the thick fimbriae of homologous and heterologous strains of that species only (table II).

(vi) The thick (type-1 or other) fimbriae of MS$\mathrm{HA}^{+}$strains of Ent intermedium. P. vulgaris, Prov. alcalifaciens and Prov. rettgeri were unreactive in IEM tests with any of the six fimbriate antisera examined (table II).

\section{Discussion}

Our previous experience has shown that the technique of IEM was invaluable in distinguishing different kinds of fimbriae formed by multifimbriated strains of several species of Enterobacter, Klebsiella and Serratia (Adegbola and Old, 1982 and 1983; Old and Adegbola, 1983 and 1984; Old et al., 1983). Moreover, our success with the application of the technique of IEM that led to the establishment of nine antigenic groups among type3 fimbriae of Enterobacteriaceae (Old and Adegbola, 1985) has encouraged us to employ the same technique for the determination of antigenic relationships among type- 1 fimbriae. Our results showed some significant differences from those of earlier reports and it was of interest to find, for example, that the type-1 fimbriae of Citrobacter were not antigenically homogeneous as had been reported previously (Duguid and Campbell, 1969; Nowotarska and Mulczyk, 1977). Thus, whereas strains of Salmonella of different sub-genera and most strains of $C$. freundi examined in this and other studies (Adegbola, 1983) formed antigenically related type-1 fimbriae, two strains of Citrobacter were shown consistently to have type-1 fimbriae antigenically related to those of Klebsiella. Did this reflect the divergence in polynucleotide sequences of some members of Citrobacter from other members of the tribe Salmonelleae as revealed by Crosa et al. (1973) or was there a simpler explanation? Though the two strains in question, strains NCTC 6071 and NCTC 9737, were received originally, and are still listed, as $C$. freundi, that identification is now in doubt (Public Health Laboratory Service, 1983). Thus, strain NCTC 6071 behaves like $C$. amalonaticus, a species significantly different by DNA-DNA reassociation from the other two named species $C$. freundi and $C$. koseri (syn. $C$. diversus) (Crosa et al., 1974). This apparently indicates, therefore, yet another example of antigenic diversity among the type- 1 fimbriae of different species within a genus. Further studies, however, are needed for a more detailed analysis of the type-1 fimbriae of Citrobacter strains especially those of $C$. amalonaticus and $C$. koseri, the latter species not having been examined by us.

Strain NCTC 9737 (Public Health Laboratory Service, 1983) is probably a species of Kluyvera, a new (i.e., recently redefined) genus of Enterobacteriaceae (Farmer et al., 1981). As judged by DNADNA reassociation, the closest relatives of Kluyvera were species of Klebsiella, Enterobacter and Citrobacter (Farmer et al., 1981). Hence, it was of interest to find that the type-1 fimbriae of this strain of Kluyvera were antigenically like those of Klebsiella and the one strain of $C$. amalonaticus examined rather than like those of Enterobacter and $C$. freundi. Further information about the haemagglutinins 
and fimbriae of the three species of Kluyvera (Farmer et al., 1985) is clearly needed.

The type-1 fimbriae of different species of Klebsiella were antigenically similar and related to those of Ent. aerogenes, a further indication that Ent. aerogenes is probably more related to Klebsiella than to other species of Enterobacter. However, the thick fimbriae of Ent. aerogenes are probably not classical type-1 fimbriae because they are not principally associated with MS-HA activity in that species (Adegbola and Old, 1985). Moreover, Ent. aerogenes is itself heterogeneous as evidenced by reports from taxonomic studies (Bascomb et al., 1971 ; Brenner et al., 1972).

Of the other currently recognised species of Enterobacter only three-Ent. amnigenus, Ent. cloacae and Ent. sakazaki-produced antigenically related type-1 fimbriae. Those formed by Ent. intermedium were antigenically distinct and the strains of Ent. gergoviae and Ent. agglomerans previously examined (Adegbola and Old, 1983) were type-1 non-fimbriate. The newly described species-Ent. taylorae, Ent. asburiae, Ent. nimipressuralis and Ent. dissolvens (Farmer et al., 1985; Brenner et al., 1986)- have not yet been examined by us. These observations were not surprising in that similar antigenic heterogeneity has been demonstrated among the type-3, and other kinds of thin, fimbriae of species of Enterobacter (Adegbola and Old, 1985; Old and Adegbola, 1985).

Among the type-1 fimbriate species of Serratia, the type-1 fimbriae of Ser. odorifera formed a distinct group and those of Ser. rubidaea, whilst showing some antigenic sharing, were less related to the other type-1 fimbriate species of Serratia. The exact taxonomic relationship of these latter two species to other serratiae requires further clarification.

The MS-HA-associated fimbriae of Proteus and Providencia were not related to each other or to those of other Enterobacteriaceae. Indeed, they seemed to be species-specific rather than, as described by Nowotarska and Mulczyk (1977), genus-specific. The recent report of Old and Adegbola (1985) has also demonstrated that the type-3 fimbriae of the different species of Proteeae are species-specific.

Previous studies (Duguid and Campbell, 1969; Nowotarska and Mulczyk, 1977) have reported antigenic relationships among the type-1 fimbriae of Escherichia, Shigella and Klebsiella. Although strains of Escherichia and Shigella were not tested by us, a recent study with an $E$. coli-derived fimgene probe for detection of frequency of the DNA sequences encoding type-1 fimbriation among Enterobacteriaceae (Buchanan et al., 1985) reported that only $E$. coli and shigellae exhibited any degree of homology. Furthermore, that study revealed that type-1 fimbrial gene sequences were present in strains of Sh. dysenteriae and $S h$. boydi, serotypes not generally reported as producing either MS-HA or type-1 fimbriae (Gillies and Duguid, 1958; Duguid and Old, 1980). Thus, these sequences are presumably either not expressed or are themselves insufficient for production of functional fimbriae. Equally intriguing is the demonstration that some isolates of $E$. coli produced three kinds of type-1 or type 1-like fimbriae (1A, 1B and 1C) with highly homologous $N$-terminal sequences (Klemm et al., 1982). However, whereas type-1A fimbriae conferred MS-HA properties and adhered to substrates, such as urinary mucus, as described for type-1 fimbriae, types $1 \mathrm{~B}$ and $1 \mathrm{C}$ were either nonhaemagglutinating or adhered to distinct substrates or both (Ørskov and Ørskov, 1983; Klemm, 1985). Thus, even one strain of one species may produce a complexity of adhesins and fimbriae so that the picture is likely to be more complex than previously described.

Our strains were chosen for this IEM study either because they produced MS-HA and associated type-1 fimbriae alone or in simple combination with other fimbriae such as type-3 fimbriae or other haemagglutinins such as MR/P-HA. We do not know whether species of Enterobacteriaceae other than E. coli also produce several kinds of type l-like fimbriae with different substrate affinities; if they do, the present IEM technique is unlikely to be sufficiently sensitive to detect them.

Type-1 fimbriae have been described as the "common" fimbriae because of their wide distribution among the species and genera of Enterobacteriaceae. Previous reports on antigenic relationships among type-1 fimbriae of Enterobacteriaceae were based essentially on findings from agglutination tests (Gillies and Duguid, 1958; Duguid and Campbell, 1969; Nowotarska and Mulczyk, 1977). Although agglutination studies were acceptable for cultures forming only one kind of fimbriae, a more sensitive technique was required for cultures that are multiply fimbriate, a common phenomenon among Enterobacteriaceae (Duguid and Old, 1980; Adegbola, 1981; Old and Scott, 1981; Adegbola and Old, 1982; Old and Adegbola, 1982; Ørskov and Ørskov, 1983; Old et al., 1983). It is significant, therefore, that with the more sensitive technique of IEM we have observed antigenic relationships more complex than those previously described for the type-1 fimbriae of 
Enterobacteriaceae. The importance of this observation on serological identification, sero-diagnosis and immunological preparations involving different enterobacteria should be noted.

\section{REFERENCES}

Adegbola R A 1981 Multiple haemagglutinins in enterobacteria. MSc thesis, University of Dundee.

Adegbola R A 1983 Fimbrial haemagglutinins of the tribe Klebsielleae. PhD thesis, University of Dundee.

Adegbola R A, Old D C 1982 New fimbrial hemagglutinin in Serratia species. Infection and Immunity 38: 306-315.

Adegbola R A, Old D C 1983 Fimbrial haemagglutinins in Enterobacter species. Journal of General Microbiology 129 : 2175-2180.

Adegbola R A, Old D C 1985 Fimbrial and non-fimbrial haemagglutinins in Enterobacter aerogenes. Journal of Medical Microbiology 19 : 35-43.

Adegbola R A, Old D C, Senior B W 1983 The adhesins and fimbriae of Proteus mirabilis strains associated with high and low affinity for the urinary tract. Journal of Medical Microbiology 16 : 427-431.

Bascomb S, Lapage S P, Willcox W R, Curtis M A 1971 Numerical classification of the tribe Klebsielleae. Journal of General Microbiology 66: 279-295.

Brenner D J, McWhorter A C, Kai A, Steigerwalt A G, Farmer J J 1986 Enterobacter asburiae sp. nov., a new species found in clinical specimens, and reassignment of Erwinia dissolvens and Erwinia nimipressuralis to the genus Enterobacter as Enterobacter dissolvens comb. nov. and Enterobacter nimipressuralis comb. nov. Journal of Clinical Microbiology 23: 1114-1120.

Brenner D J, Steigerwalt A G, Fanning G R 1972 Differentiation of Enterobacter aerogenes from klebsiellae by deoxyribonucleic acid reassociation. International Journal of Systematic Bacteriology 22: 193-200.

Buchanan K, Falkow S, Hull R A, Hull S I 1985 Frequency among Enterobacteriaceae of the DNA sequences encoding type 1 pili. Journal of Bacteriology 162: 799-803.

Crosa J H, Brenner D J, Ewing W H, Falkow S 1973 Molecular relationships among the Salmonelleae. Journal of Bacteriology 115 : 307-315.

Crosa J H, Steigerwalt A G, Fanning G R, Brenner D J 1974 Polynucleotide sequence divergence in the genus Citrobacter. Journal of General Microbiology 83 : 271-282.

Duguid J P 1959 Fimbriae and adhesive properties in Klebsiella strains. Journal of General Microbiology 21 : 271-286.

Duguid J P 1985 Antigens of type-1 fimbriae. In: Stewart-Tull D E S, Davies M (eds) Immunology of the bacterial cell envelope. Wiley, Chichester, pp 301-318.

Duguid J P, Campbell I 1969 Antigens of the type-1 fimbriae of salmonellae and other enterobacteria. Journal of Medical Microbiology 2: 535-553.

Duguid J P, Gillies R R 1957 Fimbriae and adhesive properties in dysentery bacilli. Journal of Pathology and Bacteriology 74: 397-411.

Duguid J P, Old D C 1980 Adhesive properties of Enterobacteriaceae. In: Beachey E H (ed) Bacterial adherence (Receptors and recognition, series $B$, vol. 6). Chapman and Hall, London, pp 185-217.
We thank colleagues who donated strains and supplied information about them. Dr B. Holmes afforded helpful discussion regarding the strain identities of citrobacters. RAA, an Oyo State Scholar, thanks the Committee of Vice-Chancellors and Principals (UK) for an Overseas Research Student award.

Duguid J P, Anderson E S, Campbell I 1966 Fimbriae and adhesive properties in salmonellae. Journal of Pathology and Bacteriology 92: 107-138.

Farmer J J et al. 1981 Kluyvera, a new (redefined) genus in the family Enterobacteriaceae : identification of Kluyvera ascorbata sp. nov. and Kluyvera cryocrescens sp. nov. in clinical specimens. Journal of Clinical Microbiology 13: 919-933.

Farmer J J et al. 1985 Biochemical identification of new species and biogroups of Enterobacteriaceae isolated from clinical specimens. Journal of Clinical Microbiology 21 : 46-76.

Gillies R R, Duguid J P 1958 The fimbrial antigens of Shigella flexneri. Journal of Hygiene 56: 303-318.

Klemm P 1985 Fimbrial adhesins of Escherichia coli. Reviews of Infectious Diseases 7: 321-340.

Klemm P, Ørskov I, Ørskov F 1982 F7 and type 1-like fimbriae from three Escherichia coli strains isolated from urinary tract infections: protein chemical and immunological aspects. Infection and Immunity 36: 462-468.

Korhonen T K, Tarkka E, Ranta H, Haahtela K 1983 Type 3 fimbriae of Klebsiella sp.: molecular characterization and role in bacterial adhesion to plant roots. Journal of Bacteriology 155: 860-865.

Nowotarska M, Mulczyk M 1977 Serologic relationship of fimbriae among Enterobacteriaceae. Archivum Immunologiae et Therapiae Experimentalis 25: 7-16.

Old D C 1985 Haemagglutination methods in the study of Escherichia coli. In: Sussman $\mathbf{M}$ (ed) The virulence of Escherichia coli: reviews and methods. Academic Press, Orlando, FL, pp 287-313.

Old D C, Adegbola R A 1982 Haemagglutinins and fimbriae of Morganella, Proteus and Providencia. Journal of Medical Microbiology 15: 551-564.

Old D C, Adegbola R A 1983 A new mannose-resistant haemagglutinin in Klebsiella. Journal of Applied Bacteriology 55: $165-172$.

Old D C, Adegbola R A 1984 A comparative immunoelectronmicroscopical study of fimbriae of Enterobacter and Klebsiella. Systematic and Applied Microbiology 5: 157-168.

Old D C, Adegbola R A 1985 Antigenic relationships among type-3 fimbriae of Enterobacteriaceae revealed by immunoelectronmicroscopy. Journal of Medical Microbiology 20 : 113-121.

Old D C, Payne S B 1971 Antigens of the type-2 fimbriae of salmonellae: "cross-reacting material" (CRM) of type-1 fimbriae. Journal of Medical Microbiology 4: 215-225.

Old D C, Scott S S 1981 Hemagglutinins and fimbriae of Providencia spp. Journal of Bacteriology 146: 404-408.

Old D C, Adegbola R A, Scott S S 1983 Multiple fimbrial haemagglutinins in Serratia species. Medical Microbiology and Immunology 172: 107-115.

Old D C, Tavendale A, Senior B W 1985 A comparative study of the type-3 fimbriae of Klebsiella species. Journal of Medical Microbiology 20 : 203-214.

Ørskov I, Ørskov F 1983 Serology of Escherichia coli fimbriae. Progress in Allergy 33: 80-105.

Public Health Laboratory Service 1983 Catalogue of the National 
Collection of Type Cultures, 6th edn. Public Health Laboratory Service, London, p 22.

Richard C 1977 Présence chez Enterobacteraerogenes d'antigènes capsulaires apparentés à ceux de Klebsiella. Intérêt de l'utilisation du métahydroxybenzoate dans le diagnostic différentiel E. aerogenes-K. pneumoniae. Annales de Microbiologie 128A : 289-295.

Salit I E, Gotschlich E C 1977 Hemagglutination by purified type 1 Escherichia coli pili. Journal of Experimental Medicine 146: 1169-1181. 